\title{
The Natural Hand Sanitizer Stamping Dispenser KKN Covid 19 UNS Bumirejo Village, Kecamatan Kebumen, Kabupaten Kebumen
}

\author{
Budi Legowo \\ Universitas Sebelas Maret \\ pakbeel@staff.uns.ac.id
}

\section{Article History}

accepted 31/08/2020

\begin{abstract}
UNS Covid19 KKN is a Thematic KKN held by Sebelas Maret University which was held in an individual format during the pandemic period. A total of 20 students were included in the Group of 87 KKN Covid19 UNS Batch 2 with a service area in Kebumen Regency. The implementation of appropriate technology for the stamping model of the dispenser with natural hand sanitizer aims to reduce the risk of spreading the virus from hand to hand. The stamping model dispenser was made of PVC as the main ingredient, and natural hand sanitizer was made from a mixture of betel and lime leaves. Four sets of tools were distributed in places of worship, mosques / prayer rooms in Bumirejo Village, Kebumen District, Kebumen Regency. The results of the program evaluation showed the public's appreciation of the appropriate technology made. The production cost for the dispenser was still quite expensive, so it was necessary to look for alternative raw materials to replace it. The aroma of betel leaf is still too dominant so it was necessary to find the right composition.
\end{abstract}

Keywords: KKN UNS Covid19, Stamping Dispenser Model, Natural Hand Sanitizer.

\begin{abstract}
Abstrak
Universitas Sebelas Maret menyelenggarakan Kuliah Kerja Nyata Tematik dengan format individu selama masa pandemi. Sebanyak 20 mahasiswa masuk dalam Kelompok 87 KKN Covid 19 UNS Batch 2 yang mengabdi di Kabupaten Kebumen. Implementasi teknologi tepat guna dispenser model injak dengan hand sanitizer alami bertujuan untuk mengurangi resiko penyebaran virus dari tangan ke tangan. Dispenser model injak dibuat dengan bahan utama PVC, dan hand sanitizer alami dibuat dari campuran daun sirih dan jeruk nipis. 4 (empat) set alat didistribusikan di tempat ibadah, Masjid/Musholla di Desa Bumirejo, Kecamatan Kebumen, Kabupaten Kebumen. Pelatiihan pemanfaatan dispenser model injak dilaksanakan untuk masing-masing takmir sehingga dapat diajarkan pada jamaah dan masyarakat sekitar. Hasil evaluasi program menunjukkan apresiasi positif dari masyarakat terhadap teknologi tepat guna yang dibuat. Ongkos produksi dispenser dirasa masih mahal sehingga perlu dicari alternatif bahan baku pengganti. Aroma daun sirih sebagai bahan utama hand sanitizer alami masih terlalu dominan sehingga perlu dicari komposisi yang tepat.
\end{abstract}

Kata kunci: KKN Covid19 UNS, Dispenser Model Injak, Hand Sanitizer Alami.

Social, Humanities, and Education Studies (SHEs): Conference Series https://jurnal.uns.ac.id/shes 


\section{PENDAHULUAN}

Dengan pertimbangan tidak adanya kepastian pandemi Covid19 kapan akan berakhir, Unit Pengelola Kuliah Kerja Nyata (UPKKN UNS) tetap menyelenggarakan KKN reguler pada semester genap Februari-Juli 2020. Metode pelaksanaan KKN dimasa pandemi Covid-19 yakni, mahasiswa melaksanakan program kerja secara individu di tempat tinggal masing-masing di bawah arahan Dosen Pembimbing Lapangan (DPL) secara daring (Solikah, 2020). Proses pengajuan proposal, pendampingan pelaksanaan dan penyusunan laporan kegiatan sepenuhnya dilakukan secara daring dari tempat tinggal masing-masing. Pelepasan sebanyak 2.045 mahasiswa peserta KKN Covid 19 UNS dilakukan oleh Menteri Desa, Pembangunan Daerah Tertinggal dan Transmigrasi (PDTT) Republik Indonesia, Drs. H. Abdul Halim Iskandar, M.Pd. pada tanggal 15 Mei 2020. Penerjunan peserta KKN Covid 19 UNS berlangsung selama 45 hari kerja sampai penarikan tanggal 30 Juni 2020 (Ratri, 2020).

Covid-19 yang berasal dari Wuhan di China saat ini telah menyebar ke 6 benua dan meliputi lebih dari 66 negara (Di Wu, et all, 2020). Badan Kesahatan Dunia (WHO), menganjurkan 12 cara yang dapat dilakukan sebagai upaya pencegahan persebaran Covid-19 yang sangat mudah dilakukan secara individu. Salah satu upaya yang sangat dianjurkan untuk mencegah persebaran virus adalah melakukan tindakan sanitasi dengan membersihkan jari jemari menggunakan sabun dan cairan hand sanitizer antiseptik (Pengbo Lie, et all, 2010). Hand sanitizer antiseptik dapat efektif mencegah multiplikasi mikro organisme pada permukaan tubuh, dengan cara membunuh mikro organisme tersebut atau menghambat pertumbuhan dan aktivitas metaboliknya (Fajar \& Siti, 2013). Jeruk nipis merupakan salah satu bahan alami yang bisa digunakan sebagai bahan utama pembuatan hand sanitizer. Perasan air jeruk nipis memiliki efek anti bakteri dalam menghambat pertumbuhan bakteri Staphylococcus aureus (Pramulani \& Ani, 2018). Daun sirih sebagai bahan alami pengobatan tradisional terbukti efektif menekan pertumbuhan bakteri dan virus, seperti SARS dan flu burung. Kadar ekstrak daun sirih memiliki aktivitas yang sama dengan sediaan triklosan dalam menghambat pertumbuhan mikro organisma (Retno \& Dewi, 2006).

Merujuk pada Pusat Pengendalian dan Pencegahan Penyakit AS (CDC), salah satu cara mencegah persebaran virus corona adalah dengan membersihkan permukaan benda yang sering disentuh meliputi: meja, gagang pintu, saklar lampu, alat dapur, toilet, kran air, wastafel dan lain sebagainya (Dandy, 2020). Botol hand sanitizer memiliki potensi tinggi sebagai media perpindahan, sehingga pembuatan dispenser model injak merupakan pilihan aplikasi teknologi tepat guna yang sesuai dalam mengurangi potensi perpindahan virus dari tangan ke tangan.

Isni Mei Asih mahasiswa Pendidikan Matematika dan Istiqomah Faizah mahasiswa Pendidikan Bahasa Inggris Fakultas Keguruan dan IImu Pendidikan UNS adalah dua di antara 20 peserta kelompok 87 KKN Covid-19 UNS di Kelurahan Bumirejo, Kecamatan Kebumen, Kabupaten Kebumen yang secara kebetulan tinggal pada lingkungan RW yang sama. Dengan pertimbangan masih rendahnya kepedulian masyarakat dalam melaksanakan protokol kesehatan pencegahan Covid-19, utamanya dalam menjaga kebersihan tangan, kedua peserta dalam satu wilayah tersebut selanjutnya melaksanakan program kolaborasi dalam pembuatan dispenser model injak dengan hand sanitizer alami daun sirih jeruk nipis. Kolaborasi pelaksanaan program oleh dua mahasiswa peserta KKN Covid-19 UNS tetap memperhatikan aturan pelaksanaan dengan cara melakukan pembatasan interaksi dengan masyarakat baik dalam segi jumlah individu yang terlibat maupun durasi selama proses pembuatan, ujicoba dan pelatihan pemanfaatan teknologi. Masjid dan musholla dipilih sebagai sasaran implementasi karena merupakan pusat kegiatan ibadah dan interaksi masyarakat sehingga mudah dalam melakukan transfer pengetahuan dan peningkatan kesadaran melaksanakan protokol kesehatan. 


\section{METODE PELAKSANAAN}

Implementasi teknologi tepat guna dispenser model injak dengan hand sinitizer alami dilakukan dalam rangka KKN Covid-19 UNS di Desa Bumirejo Kecamatan Kebumen Kabupaten Kebumen. Metode pelaksanaan implemantasi teknologi tepat guna meliputi: 1.) Pembuatan dispenser model injak, 2.) Pembuatan hand sanitizer alami 3.) Pemanfaatan di masjid/Musholla, dan 4.) Evaluasi program

\section{Pembuatan Dispenser Model Injak}

Bahan utama pembuatan dispenser model injak adalah pipa PVC. Untuk satu set dispenser model injak dibutuhkan pipa PVC ukuran 3/4 inch penyangga bawah, pipa PVC ukuran $1 \frac{1 / 4}{4}$ inch kolong penyangga utama, pipa PVC ukuran 4 inch untuk tempat botol, serta beberapa sambungan pipa (keni dan tee), tutup pipa (dop) dan lem PVC. Skema dispenser model injak ditunjukkan pada Gambar 1 berikut,

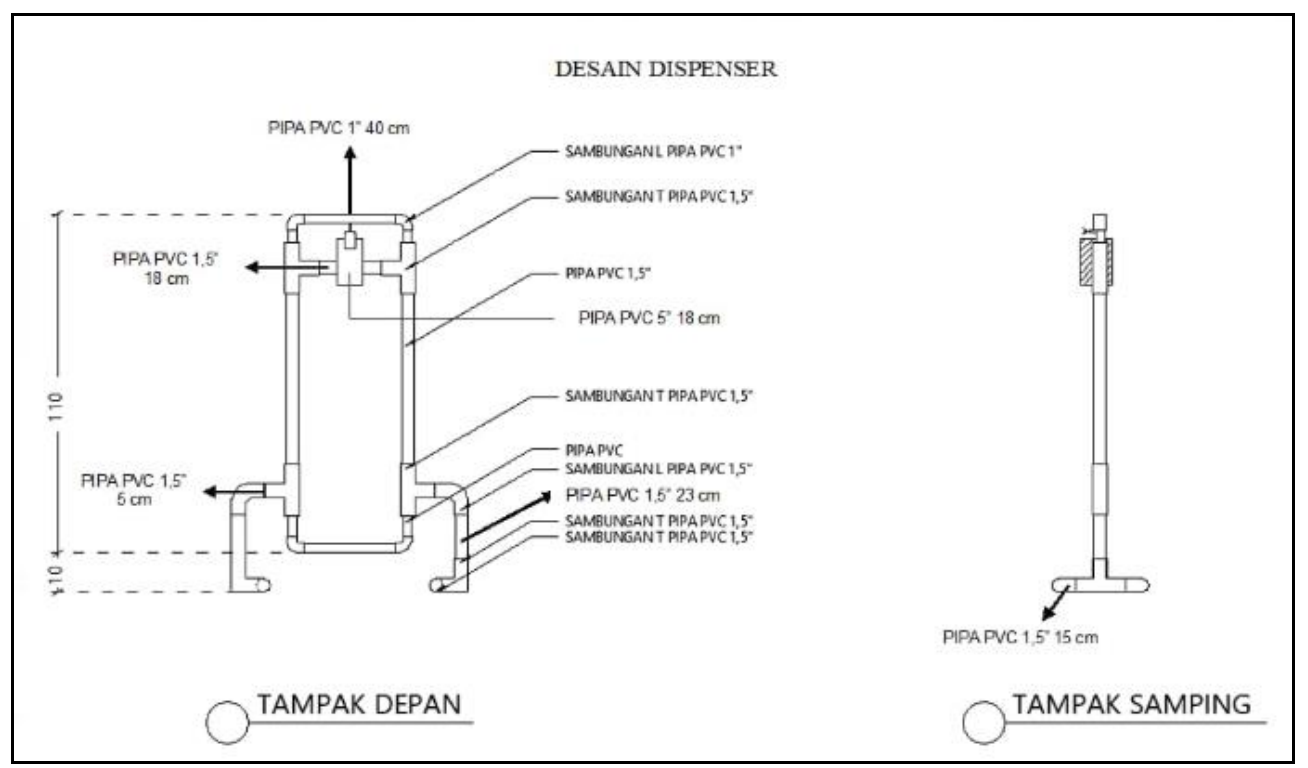

Gambar 1. Skema Dispenser Model Injak

PVC dipilih sebagai bahan utama pembuatan dispenser model injak karena relatif murah, ringan dan sangat mudah dalam pembuatan jika dibandingkan dengan bahan baku dari logam/besi. Proses pembatan dapat menggunakan alat sederhana yang murah dan mudah di dapat di pasaran. Bentuk dan ukuran dispenser mudah disesuaikan dengan kebutuhan. Sambungan dapat dibuat secara permanen maupun dengan cara bongkar pasang tanpa pengeleman jika diperlukan.

Kerja mekanik dari dispenser ini adalah berfungsinya pedal ijak sebagai pengganti tangan untuk memencet kran botol hand sanitizer. Langkah ini diharapkan dapat mengurangi potensi berpindahnya virus dari tangan ke tangan. Dispenser model injak ditunjukkan pada Gambar 2. Mengingat bahan utama yang ringan, stabilitas rangkaian PVC saat diinjak merupakan pertimbangan utama. Melebarkan kaki dispenser merupakan cara yang dipilih agar tidak mudah rubuh saat diinjak/digunakan. Rangkaian PVC sebagai bahan utama pembuatan dispenser model injak dapat digantikan dengan bambu jenis apus yang tipis dengan rongga cukup lebar. Pemilihan bambu sebagai bahan alternatif dengan pertimbangan kelimpahan sediaan di desadesa. Dispenser injak dengan bahan dasar bambu apus juga memiliki segi artistik lebih baik sehingga dapat berfungsi seperti layaknya pajangan/hiasan. 


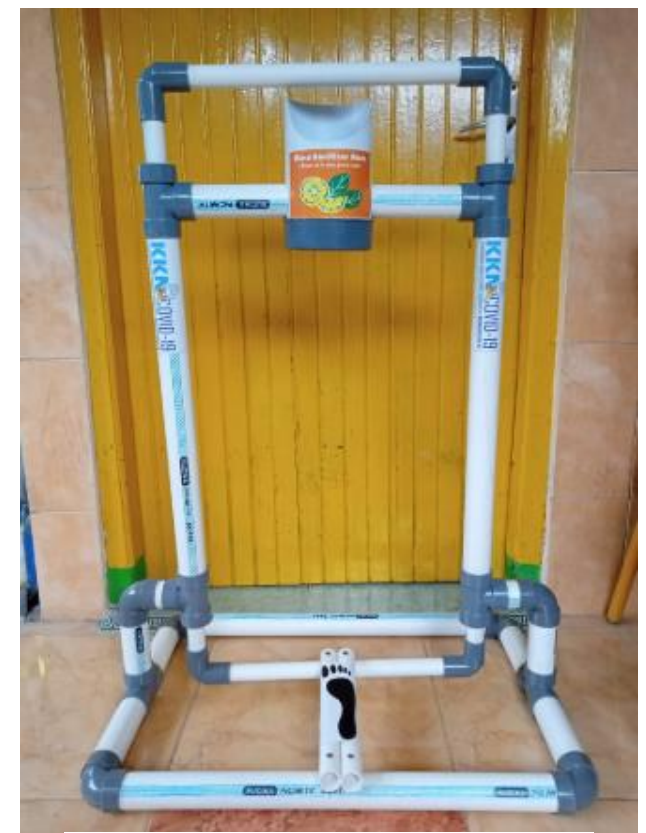

Gambar 2. Dispenser Model Injak

\section{Pembuatan Hand Sanitizer Alami}

Bahan utama hand sanitizer alami yang digunakan adalah daun sirih dan jeruk nipis dengan perbandingan 1:1. Metode pembuatan dengan cara direbus dan selanjutnya diperas untuk diambil sarinya. Cara pembuatan tanpa ekstraksi ini dipilih agar masyarakat dapat dengan mudah membuatnya sendiri sesuai dengan kebutuhan. Proses pembuatan hand sanitizer ditunjukkan pada Gambar 3 berikut,

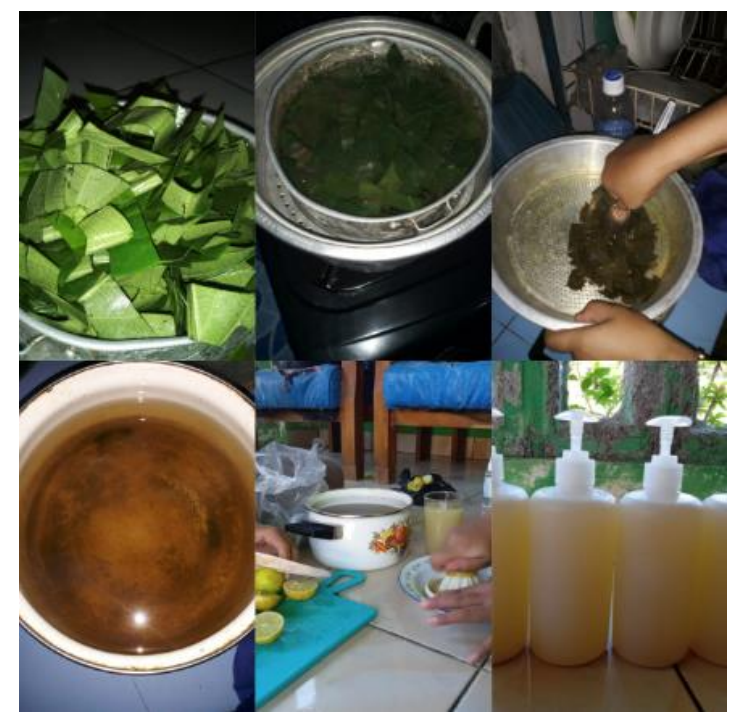

Gambar 3. Proses Pembuatan Hand Sanitizer Alami

Edukasi pembuatan cairan hand sanitizer ini melibatkan anggota PKK di Desa Bumirejo. Anggota PKK yang sebagian besar ibu rumah tangga memiliki pengalaman yang cukup dalam proses pengolaahan rebus peras. Pengetahuan yang dimiliki dapat dikembangkan untuk membuat hand sanitizer untuk kebutuhan sendiri atau produksi. Potensi pengembangan produksi sangat tinggi mengingat bahan baku yang melimpah dan mudah diperoleh di lingkungan sekitar. 
Proses pembotolan dilakukan secara manual setelah cairan hand sanitizer didinginkan. Cairan hand sanitizer alami daun sirih dan jeruk nipis ini dapat disimpan selama 2-4 minggu sebelum penggunaan. Hand sanitizer dalam kemasan $250 \mathrm{ml}$ ditunjukkan dalam Gambar 4. Kemasan $250 \mathrm{ml}$ dipilih dengan beberapa pertimbangan, diantaranya adalah durasi penyimpanan dan menyesuakan ketersediaan ukuran PVC di pasaran.

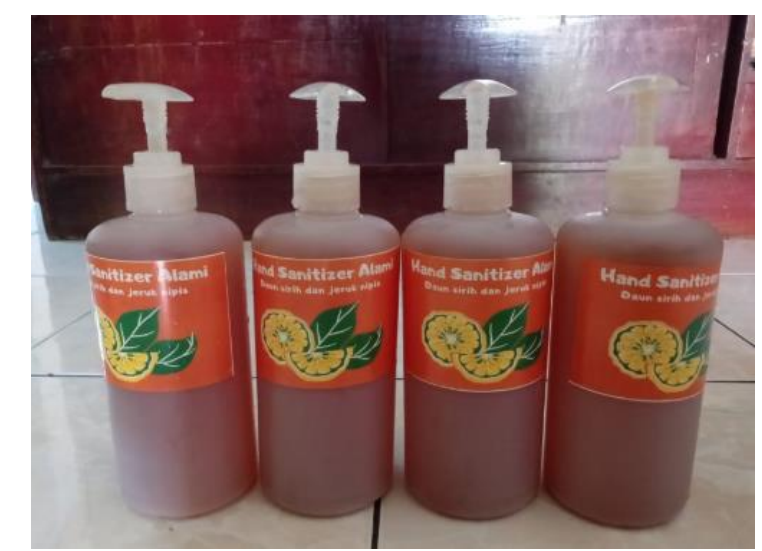

Gambar 4. Hand Sanitizer Alami Kemasan 250 ml

\section{Pemanfaatan di Masjid/Musholla}

\section{HASIL DAN PEMBAHASAN}

Masjid dan musholla dipilih sebagai tempat pemanfaatan dispenser injak dengan hand sanitizer alami karena merupakan fasilitas umum yang banyak terjadi aktivitas warga. Tempat ibadah juga menjadi salah satu tempat potensial persebaran Covid 19. Kesadaran jamaah/masyarakat lingkungan tempat ibadah yang masih rendah, mendorong perlunya edukasi untuk melakukan protokol kesehatan pencegahan persebaran Covid-19, salah satunya dengan rajin cuci tangan dan menggunakan hand sanitizer.

Adapun masjid dan mushola yang sasaran pembagian dispenser injak dengan hand sanitizer alami adalah Masjid Babussalam RT 02/04, Masjid Jami' Al-Falah RT 03/04, Mushola Darussalam RT 02/04, dan Mushola Al-Muttaqin RT 05/04, Bumirejo, Kebumen. Serah terima dispenser injak dengan hand sanitizer alami ditunjukkan dalam Gambar 5, berikut
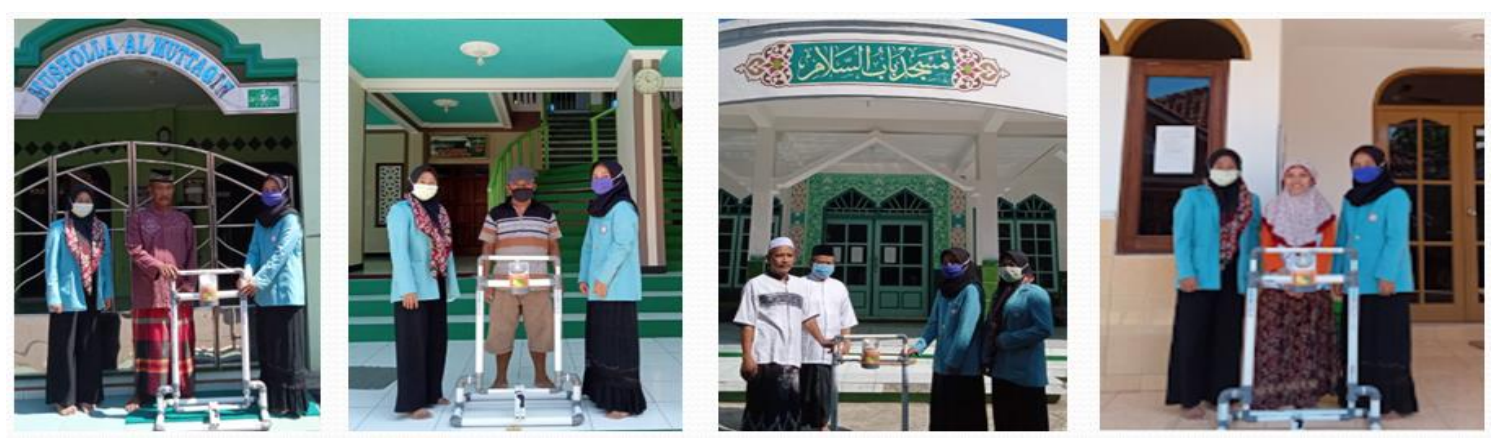

Gambar 5. Serah terima dispenser injak dengan hand sanitizer alami

Pelatihan pengguaan dispenser model injak dengan hand sanitizer alami dilaksanakan saat serah terima diikuti oleh masing-masing takmir. Pengetahuan pengurngan resiko persebaran Covid 19 dari tangan ke tangan selanjutnya diharapkan dapat diteruskan pada jamaah dan masyarakat lingkungan tempat ibadah berada. 


\section{Evaluasi program}

Untuk melihat respon masyarakat terhadap pemanfaatan dispenser injak dengan hand sanitizer alami di masjid dan musholla Desa Bumirejo dilakukan evaluasi dengan metode kuisoner, seperti ditunjukkan pada Gambar 6. Mengingat kemampuan teknologi informasi yang sangat beragam pada masyarakat sasaran, evaluasi tidak dapat dilakukan secara daring menggunakan kusioner daring. Dengan tetap mematuhi protokol kesahatan, terutama physical distancing, kusioner evaluasi penggunaan dispenser model injak dengan hand sanitizer alami dilakukan secara luring.

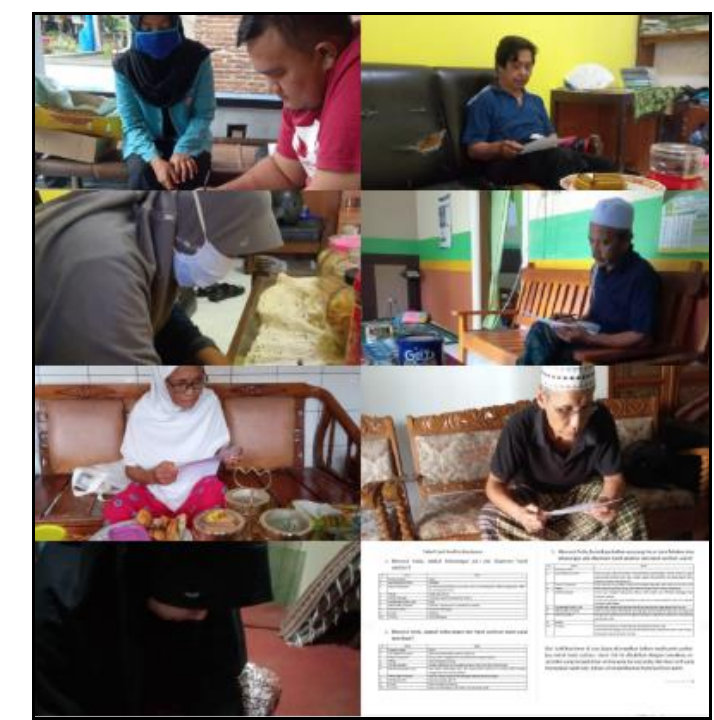

Gambar 6. Evaluasi Melalui Pengisian Kuisioner

Hasil evaluasi menunjukkan apresiasi yang sangat baik terhadap pemanfaatan teknologi tepat guna di tempat ibadah. Teknologo tepat guna yang di aplikasikan sangat mudah digunakan dan dipindah-pindahan sesuai kebutuhan. Penggantian botol hand sanitizer dan perawatan mudah dilakukan karena bahan platik dan PVC yang mudah dibersihkan. Dispenser model injak dengan bahan baku utama dirasa masih terlalu mahal untuk diproduksi dan digunakan secara masal di rumah-rumah warga. Aroma daun sirih masih terlalu dominan dan dirasa cukup mengganggu, terutama untuk jamaah pria. (Budi, 2020).

\section{SIMPULAN DAN SARAN}

Pemanfaatan teknologi tepat guna berupa dispenser model injak dengan hand sanitizer alami daun sirih dan jeruk nipis diterima masyarakat dengan baik. Penggunaan bahan alternatif selain PVC diharapkan dapat menekan ongkos produksi sehingga teknologi ini dapat digunakan secara masal oleh masyarakat di rumah masing-masing. Formula hand sanitizer perlu disempurnakan untuk mengurangi aroma daun sirih yang lebih dominan tanpa mengurangi manfaat dan fungsinya. 
DAFTAR PUSTAKA

Budi, L. (2020, Juli 2). Jawa Pos. Retrieved Juli 5, 2020, from jpnn.com: https://m.jpnn.com/news/kkn-covid-19-uns-handsanitizer-bahan-alami-dandispenser-injak-mendapat-apresiasi?page $=2$

Dandy, B. B. (2020, Maret 2020). Nees Kompas. Retrieved Juni 1, 2020, from kompas.com:

https://www.kompas.com/tren/read/2020/03/19/055000365/cegah-penyebaranvirus-corona-berikut-cara-mudah-bersihkan-dan-disinfektan?page=all

Di Wu, Tiantian Wu, Qun Liu, Zhicong Yang, The Sars-CoV-2 outbreak: What we know, International Journal of Infectius Diseases, 94 (2020), p 44-48.

Fajar, A. D., \& Siti, N. D. (2013). Efektivitas Mencuci Tangan Menggunakan Cairan Pembersih Tangan Antiseptik (Hand Sanitizer) Terhadap Jumlah Angka Kuman. KesMas: Jurnal Fakultas Kesehatan Masyarakat, 75-82.

Pengbo Liu, Yvonne Yuen, Hui-Mien Hsiao, Lee-Ann Jaykus, Christine Meo, Effectiveness of Liquid Soap and Hand Sanitizer against Norwalk Virus pn Contaminated Hands, Applied and Environmental Microbiology, 76 (2010), pp 394-399

Pramulani, M. L., \& Ani, P. (2018). Pelatihan Pembuatan Hand Sanitizer Perasaan Buah Jeruk Nipis Bagi Guru, Siswa Siswi SMA dan SMK Mutiara 17 Agustus Kelurahan Teluk Pucung Bekasi Utara. SEMAR: Jurnal IImu Pengetahuan, Teknologi dan Seni bagi Mastyarakat, 20-24.

Ratri. (2020, Mei 16). Humas UNS. Retrieved Juni 2020, 1, from uns.ac.id: https://uns.ac.id/id/covid-19/sebanyak-2-045-mahasiswa-uns-ikuti-kkn-covid-19tahap-dua.html

Retno, S., \& Dewi, I. (2006). Studi efektifitas sediaan gel antiseptik tangan ekstrak daun sirih (piper betle Linn.). Majalah Farmasi Indonesia, 163-169.

Solikah, B. (2020, Mei 15). News Republika. Retrieved Juli 2020, 1, from republika.co.id: https://republika.co.id/berita/qacv7m335/mahasiswa-uns-jalanikkn-covid19-tahap-kedua 